\title{
Exploring the Parameters of China's Economic Influence
}

\author{
Scott L. Kastner ${ }^{1} \cdot$ Margaret M. Pearson $^{1}$
}

Accepted: 30 January 2021 / Published online: 5 March 2021

(C) The Author(s), under exclusive licence to Springer Science+Business Media, LLC part of Springer Nature 2021

\begin{abstract}
To what extent do China's linkages to the global economy translate into political influence in other countries? This topic is the focus of copious amounts of policy and scholarly attention in the USA and around the world. Yet without thoughtful conceptualization of key assumptions and creation of research designs that allow identification of mechanisms of potential influence, we cannot gain an accurate understanding of Chinese influence. How can we assess Beijing's intentions? Through what mechanisms - both intended and unintended - might influence arise, and under what conditions is influence most likely to occur? To what degree are Chinese companies agents of the state and therefore tools of economic statecraft? What factors condition how host countries react to economic ties with China? In this article, we explore existing scholarship on these questions, and assess promising directions for future research.
\end{abstract}

Keywords China $\cdot$ Influence $\cdot$ Sanctions $\cdot$ Belt road initiative $\cdot$ Foreign direct investment . Foreign aid $\cdot$ State-owned enterprises

\section{Introduction}

As the world faces a pandemic-induced economic crisis, China remains a pillar of the global economy. Only four decades after the initiation of reform and opening, the People's Republic of China (PRC) has emerged as an economic giant and is now the world's second largest economy and largest trading nation. The PRC has become the largest or second largest trading partner of nearly every country in East, Central, and

Margaret M. Pearson

mpearson@umd.edu

Scott L. Kastner

skastner@umd.edu

1 Department of Government and Politics, University of Maryland, College Park, 3140 Tydings Hall, College Park, MD 20742, USA 
South Asia, and its economic ties (in terms of trade, investment, and aid) with the rest of the world are immense.

China's expanding global economic footprint, in turn, has given rise to a conventional wisdom that the PRC's overseas influence is growing in tandem. Indeed, the US government views expanded influence as a key motivation behind China's massive Belt and Road Initiative (BRI). Recent US Department of Defense reports assert that "China intends to use [BRI] to develop strong economic ties with other countries, shape their interests to align with China's, and deter confrontation or criticism of China's

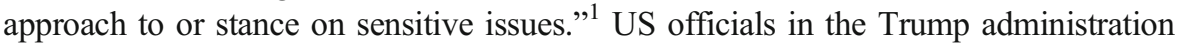
routinely framed BRI as an "influence operation." Former US Secretary of State Mike Pompeo, for instance, described BRI as involving "corrupt infrastructure deals in exchange for political influence," 2 and former US National Security Advisor John Bolton argued that "China uses bribes, opaque agreements and the strategic use of debt to hold states in Africa captive to Beijing's wishes and demands."3

Nevertheless, the relationship between China's foreign economic ties and its overseas influence is in fact quite complicated. On the one hand, it is relatively easy to find cases where China's growing economic power has enabled Beijing to exert influence over political decisions in other countries. For example, several countries in recent years have allowed economic ties with China to alter their approach to the Dalai Lama. In one high-profile case, British Prime Minister David Cameron-facing tacit sanctions after a 2012 meeting with the Dalai Lama - did a U-turn and agreed to refuse future meetings with the spiritual leader. ${ }^{4}$ On the other hand, we can also point to cases where even extensive economic integration fails to generate obvious influence. For instance, Taiwan's economy is heavily dependent on economic ties to China, yet voters reelected Tsai Ing-wen as president in a landslide despite Beijing's obvious antipathy toward her. Sometimes China's foreign economic ties even create backlash, as when Malaysian Prime Minister Mahathir Mohamad warned about overdependence on Chinese loans and the danger of "debt traps." During the coronavirus crisis of 2020-2021, China's efforts to leverage "mask diplomacy" to improve China's image overseas have sometimes backfired because such efforts have appeared overtly designed to advance political goals. ${ }^{6}$ In short, the relationship between China's growing links to the global economy and PRC influence abroad varies considerably across cases; in some cases, economic ties may actually undercut influence.

In the pages that follow, we explore this ambiguous relationship between China's expansive global economic footprint and its influence abroad. Our aim is to take stock of existing literature on China's economic influence, to identify key gaps and problems emerging in existing studies, and to set agenda priorities for future research. We

\footnotetext{
${ }^{1}$ U.S. Department of Defense 2018: 12. See also, e.g., U.S. - China Economic and Security Review Commission Annual Report to Congress 2018: 288.

${ }^{2}$ Reuters, 9 May 2019: https://www.reuters.com/article/us-china-silkroad-usa/china-says-fed-up-withhearing-u-s-complaints-on-belt-and-road-idUSKCN1SF0UY.

${ }^{3}$ Quoted in Khanna 2019.

${ }^{4}$ Reuters, 1 December 2013: http://uk.reuters.com/article/uk-britain-china-cameronidUKBRE9AT05G20131201.

${ }^{5}$ The Straits Times, 8 March 2019: https:/www.straitstimes.com/asia/beware-of-china-debt-trap-mahathir.

${ }^{6}$ Time, 3 April 2020: https://time.com/5814940/china-mask-diplomacy-falters/.
} 
structure our discussion around four questions relating to China's growing overseas economic footprint.

- Intent: To what degree, and in what domains (military, economic, political, etc.), does China's government intend to leverage foreign economic ties to increase its influence abroad?

- Mechanisms of influence: What are the causal mechanisms through which China's foreign economic ties might translate into influence abroad?

- Firms as state agents: Are PRC firms willing agents of the Chinese state, and what are the implications for China's ability to exert influence abroad?

- Reactions: How do countries in which Chinese economic activities are carried out react to those activities and to the possibility of influence? Under what conditions do China's economic ties to other countries lead to either positive acceptance of or, alternatively, marginal influence or even negative backlash against Chinese interests?

Before proceeding to these questions, a few words about scope are in order. We are interested in whether and how China's global economic ties affect policy choices in other countries, such that these policies come more into line with Beijing's preferences. Thus, we conceptualize economic influence as occurring when economic ties have such an effect. To be clear, influence does not necessarily imply intent. That is, while we imagine that Beijing may at times seek to leverage economic power to effect policy change elsewhere (an intentional effort to influence), influence may also arise through more diffuse processes, such as changed perceptions of self-interest in other countries and influence over agenda-setting. ${ }^{7}$ Furthermore, we do not directly consider other avenues (not related to China's foreign economic ties) of influence or policy convergence, such as ideology, soft power, or China's growing military power. And we also set aside highly indirect channels, such as trade generating economic growth in China that can be parlayed into increased military spending, which in turn might translate into greater Chinese influence. ${ }^{8}$

\section{Intent: does Beijing Seek to Leverage its Economic Rise for Political Influence?}

To start, it is worth asking whether and when the Chinese government intends to use its global economic footprint as a means to influence the behavior of other countries. For instance, to what degree is the massive BRI meant to increase China's influence abroad, and to what extent is it driven by other priorities such as serving the commercial goals of firms? Unfortunately, intention is often exceedingly difficult to gauge. ${ }^{9}$ While policy-makers outside of China must make assumptions about intent in the face of imperfect information, questions of whether and what? intent should be assessed

\footnotetext{
${ }^{7}$ See, e.g.: Gaventa 1982; and Lukes 1974.

${ }^{8}$ On Chinese analysts' conceptions of influence, see Glosny 2016.

${ }^{9}$ See, e.g., Yarhi-Milo 2014.
} 
explicitly, lest wrong assumptions lead to costly miscalculations. ${ }^{10}$ There is no question that the PRC government actively promotes China's overseas economic activities. Its goals in doing so, however, clearly vary across types of activities, sectors, and geographies. We can think of PRC aims in promoting foreign economic ties as falling into three broad categories: advancing PRC foreign policy and geostrategic goals; seeking to strengthen the national economy; and advancing the commercial interests of particular firms. These categories, moreover, are not mutually exclusive.

The BRI, as a cornerstone initiative of President Xi Jinping, and overseen at the highest levels of government, ${ }^{11}$ appears to fall at least partly into the first category. Authoritative Chinese statements on the BRI often emphasize the initiative's peaceful intentions, and stress it is designed to promote security and growth - often characterized as "global public goods" - in the Asian region and beyond. Xi Jinping, in his speech at the 19th Party Congress in 2017, stated: "China will actively promote international cooperation through the Belt and Road Initiative. In doing so, we hope to achieve policy, infrastructure, trade, financial, and people-to-people connectivity and thus build a new platform for international cooperation to create new drivers of shared development." 12 Chinese writings on BRI, while often short on details, emphasize that economic development will help bring growth and connectivity and that together these will promote peace and stability. ${ }^{13}$ Other observers assert that China hopes its overseas economic activities will enhance, in turn, China's global soft power and status. The idea that the PRC is a beneficent contributor to development in poor countries undergirds what some have asserted is a "China model" for development. ${ }^{14}$

Likewise, China's foreign activities often have been interpreted as intended to advance strategic military objectives. ${ }^{15}$ The connectivity China builds, some have argued, places China as the central strategic player, upon whom other countries must depend. China's projects might, furthermore, expand China's toolkit for military ventures. ${ }^{16}$ A prime example is the concern that China's investment in ports along the Indian Ocean and beyond are "strategic strongpoints" that the country can leverage for future military aggression. ${ }^{17}$ China's government itself has been clear that it prioritizes "construction of a strong maritime country," because "the status of oceans in national development dominates more than in any other period of human history."18

Meanwhile, suggestions that China is practicing "debt trap diplomacy" - in which China is said to build leverage by offering large loans for projects that are not commercially or financially viable - have become commonplace. This characterization, which suggests that China's foreign aid is driven by geostrategic goals, remains highly contested. ${ }^{19}$ Still, at times even Chinese officials are frank about geostrategic goals. For

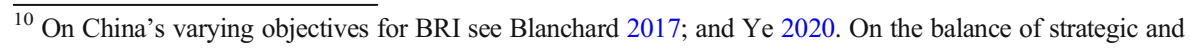
economic motivations for China's foreign economic policies more generally, see Saunders 2006.

${ }^{11}$ Rolland 2019.

${ }^{12}$ Xi 2017. See also, for example, State Council of China 2015.

${ }^{13}$ These goals are summarized in Wuthnow 2017.

${ }^{14}$ On soft power, see Brady 2015. On status, see Pu and Schweller 2014. On motives for foreign aid, see Fuchs and Rudyak (2019).

${ }^{15}$ On geostrategic intent, see: Eisenman and Heginbotham 2018; and Friedberg 2018.

${ }^{16}$ Russel and Berger 2020.

17 Kardon 2021.

18 State Oceanic Administration 2016 (p. 239).

${ }^{19}$ Bräutigam 2020
} 
instance, Beijing often frames economic policy toward Taiwan as being driven by the goal of eventual unification with the island. ${ }^{20}$ In general, the possibility that China's overseas economic activities will pave the way for geostrategic strength and comprehensive national power, even if plausibly a "normal" practice for a rising power, has caused deep suspicion outside of China. Such fears have prompted China's leaders continually to offer reassurances, not just reaffirming that it seeks "win-win" outcomes but also repeating the official claim that China "will never seek hegemony or engage in expansion." 21

A second objective underlying China's foreign economic policies may be to strengthen the national economy, which in turn improves the state's governance capacity and strengthens legitimacy of the Chinese Communist Party (CCP). Leveraging economic ties can support multiple national economic objectives, including acquisition of natural resources and advanced technology and the promotion of "national champions." Industrial policy objectives underlie some outward economic activity, as was the case with the 2009 "Harmonious World Plan" that aimed to make $\$ 500$ billion in foreign aid conditional upon preferential access to Chinese construction and equipment vendor companies. ${ }^{22}$ Others note that Beijing is mimicking Japan's "flying geese" pattern of globalization by establishing offshore trade zones and using supports such as export credits as a catalyst for their own firms' activities. ${ }^{23}$ National economic objectives also may include addressing domestic economic weaknesses. Overseas infrastructure investment, for example, helps address economic burdens of excess production capacity of China's major state-owned enterprises (SOEs). Beijing's pressure on firms to "go out," which had been present since the financial crisis of 2008-2009, intensified with the slowing of economic growth starting around $2015 .^{24}$

A third possible goal of Beijing's overseas economic policy is to facilitate and support commercial opportunities for Chinese companies. In this perspective, government activity aims to benefit firms, whether state-owned or private, in the pursuit of market opportunities. Official PRC statements often emphasize a market-conforming orientation. A major policy statement on BRI, for example, states: "The Initiative follows market operation. It will abide by market rules and international norms, give play to the decisive role of the market in resource allocation and the primary role of enterprises, and let the governments perform their due functions." ${ }^{25}$ Commercial counselors in Chinese embassies and consulates often try to smooth the way, or settle disputes, on behalf of firms. A commercial facilitation intent is standard for many countries (e.g., the US Department of Commerce Foreign Commercial Service).

These different intentions - advancing foreign policy goals, strengthening the national economy, supporting commercial opportunities - carry quite different implications for the question of influence. The first implies that Beijing aims to leverage economic ties into other types of influence, whereas the goals of promoting national

\footnotetext{
${ }^{20}$ For instance, Jiang Zemin in 1994 suggested that "increasing cross-Strait economic exchanges and cooperation...will be useful in boosting the development of cross-Strait relations and national unification." See Zhao 1999, 27.

${ }^{21} \mathrm{Xi} 2017$.

22 Ye 2020.

${ }^{23}$ Bräutigam and Tang 2012; Fuchs and Rudyak 2019.

${ }^{24}$ Kroeber 2016; Ye 2020.

25 NDRC 2015.
} 
economic growth and facilitating commercial ties suggest such leverage may be indirect or less important. Thus, a key analytic task for scholars is to correctly identify intent. As noted above, this is easier said than done. Multiple objectives can exist simultaneously and can logically lead to consistent behaviors, moreover. Chinese policy statements often link or stack commercial, economic, and foreign policy/ security objectives; a 2017 White Paper states that economic development (especially in the Asian neighborhood) helps China's firms and develops the Chinese economy as a whole; and these together contribute to China's security. ${ }^{26}$ Similarly, scholars such as Dreher et al. argue with regard to Chinese aid that a single project may be aimed at both security and economic objectives. ${ }^{27}$ The possibility that foreign economic policy may serve both security and economic goals is far from unique to China, a point often made about US foreign aid.

Difficulty ascertaining a "true" intent underlying formally stated objectives is also made challenging by features of China's policy processes. Policy debate and formulation occur largely in a black box and are expressed with opaque language. As Wuthnow notes with regard to BRI, "largely absent from China's official commentary is a discussion of the BRI's strategic benefits and security risks. Avoiding discussion of the initiative's strategic rationale helps to reduce suspicions of China's intentions, especially among other major countries." ${ }^{28}$ Moreover, with the exception of "core interests" (such as sovereign claims to Taiwan), PRC officials have long tended to frame China's foreign policy as benign, and focus on non-threatening intentions with "win-win" outcomes. ${ }^{29}$ Reference often is made to longstanding principles of Chinese foreign policy developed in the 1950s, including "non-interference" and "equality and mutual benefit." Such statements may be designed to soothe external anxieties, as well as to play to internal audiences, encouraging sometimes skeptical firms and citizens to believe it will be in their economic interest to participate in overseas initiatives.

It is worth noting that even if Chinese leaders do not wish to hide their intentions, policy may not actually be carefully crafted to achieve end goals. Indeed, while it may be tempting to interpret policies of a Leninist regime as visionary, strategic, and well-planned, Deng Xiaoping's domestic economic reforms offer an alternative precedent. The 1980s reform program that transformed China into an economic powerhouse is often portrayed ex post as having been brilliantly planned, but in fact, it did not follow a blueprint; the details of both goals and means were filled in gradually, in a drawn out and decentralized fashion. ${ }^{30}$ Similarly, broad foreign policy initiatives often start as vague slogans. The frequently noted difficulty of even defining BRI is emblematic of this feature of Chinese policy-making. ${ }^{31}$ Broadly framed initiatives serve as signals to subordinate actors (e.g., foreign policy bureaucrats and firms) but stop short of specific directives.

\footnotetext{
${ }^{26}$ SCIO 2017.

${ }^{27}$ Dreher et al 2018 use an innovative empirical strategy to argue that official aid is driven more by foreign policy considerations, while commercial factors motivate what they term "other official flows" (OOFs) that are often categorized as aid. See also Russel and Berger 2020.

${ }^{28}$ Wuthnow 2017: 7.

${ }^{29}$ E.g., NDRC 2015.

${ }^{30}$ Kroeber 2016.

${ }^{31}$ See: Jones and Zeng 2019; and Zhi and Pearson 2017.
} 
At the same time, researchers should also be cognizant of coordination and implementation challenges well-known to scholars of China's domestic politics. ${ }^{32}$ Decisions involve many principals, each of whom may have different goals. ${ }^{33}$ The PLA Navy might wish to push geostrategic advancements, whereas an industrial policy-oriented planning body (National Development and Reform Commission [NDRC]) may guide policy to create national champions, while the Ministry of Commerce (MOFCOM) may wish to provide market opportunities for firms. And despite general directions and principles expressed at the top, lower level political actors - both within China (e.g., provincial leaders) and outside of China (e.g., commercial counselors and other embassy personnel in host countries) - may use broad openings by the central government as an opportunity to go in their own direction. ${ }^{34}$ Classic problems of conflicting objectives and problematic implementation are by no means specific to China; knowledge of these fundamentals of PRC bureaucratic politics gives further reason to question easy assumptions about Beijing's intentions.

To assess intentions, analysts should both examine official statements and when possible assess the concrete terms of deals, such as for bilateral aid and investment projects. Even so, even after combing through available evidence, some level of ambiguity in Chinese intentions is likely to remain. ${ }^{35}$ Scholars should be especially cautious about imputing motives based on observed behavior. Doubling down on a money-losing port project, for example, could reflect underlying geostrategic intent, but it could also reflect moral hazard incentives and soft-budget constraints for the firms engaged in the venture. ${ }^{36}$

\section{Causal Mechanisms: How Might China's Foreign Economic Ties Translate into Political Influence?}

Studies of China's overseas economic influence should also grapple with the crucial question of how PRC foreign economic ties might translate into political influence, for at least two reasons. First, without a theory linking economic ties to political behavior, observers risk asserting influence when none in fact exists. To assess whether economic ties with China actually shape behavior of other states, scholars ultimately need a theory of how they do so; only then does it become possible to design tests that explore the theory's micro-foundations, and to assess whether the causal mechanisms underlying an influence effect are in fact operating. Second, as alluded to earlier, it is obvious that China's economic influence varies across cases and across time. Without a theory of how economic ties might lead to influence, it becomes impossible to predict when such an effect is likely to occur.

\footnotetext{
${ }^{32}$ On policy formulation and implementation challenges in China, see: Lieberthal and Oksenberg 1988; and Lieberthal and Lampton 1992. To concur with the introductory chapter in this special issue (Fravel et al. 2021), we find it crucial to understand the domestic political imperatives that shape China's foreign policymaking.

${ }^{33}$ On logrolling in foreign policy, see: Snyder 1991.

${ }^{34}$ Ye 2020.

${ }^{35}$ Wuthnow 2019.

${ }^{36}$ Ferchen and Perera 2019; Shi 2015.
} 
Unfortunately, much of the existing literature on China's overseas influence, especially in the policy domain, glazes over the causal mechanisms linking economic ties to political influence. Part of the problem is that there exist numerous different plausible pathways to an influence effect, and assessing which pathway is likely to be most salient in a given context can be difficult. Further complicating matters is the difficulty in assessing whether the PRC actually intends, in any given situation, to leverage its foreign economic ties to advance political goals. Finally, and complicating things still further, China's foreign economic ties can potentially translate into influence abroad even in the absence of intent.

In this section, we consider how China's foreign economic ties might lead to increased political influence abroad. We describe four separate causal logics that could underlie an influence effect. First, economic ties can be a source of bargaining power, giving Beijing more tools through which to reward compliance or punish noncompliance with China's preferred policies. Second, economic ties can generate new interest groups in countries that come to depend on China economically. Third, economic ties can help to shape broader public and elite opinion about China in a particular country, influencing the views of even those without a direct economic stake in the PRC. Finally, economic ties can potentially lead to structural power, where Beijing has the power to set standards and shape markets to which the rest of the world must adapt. We further observe that each of these causal logics either can occur intentionally or can emerge as an unintended externality of economic integration with the PRC. ${ }^{37}$

\section{Economic Ties as a Source of Bargaining Power}

In the first and most direct causal logic, China's growing foreign economic ties could increase Beijing's bargaining power vis-à-vis other countries. As countries become more economically dependent on China, they potentially become more vulnerable to PRC "sticks," i.e., coercive economic statecraft, where Beijing either threatens or imposes economic sanctions as a way to shape target behavior. Economic ties also give Beijing the opportunity to pursue "carrots," i.e., inducement strategies, in which favorable target behavior is rewarded. And the presence of economic ties themselves could be the result of a linkage strategy, as a reward for accommodating Chinese interests in some way.

\section{Coercive Economic Statecraft}

Coercive (or negative) economic statecraft occurs when a country threatens or imposes economic sanctions as a way to increase the likelihood of preferred behavior by a target. In the broader international relations literature, numerous studies assess the utility of economic sanctions as a policy instrument. Studies reach diverging conclusions, ${ }^{38}$ however, in part because assessing "success" is challenging. ${ }^{39}$ Moreover, it can

\footnotetext{
${ }^{37}$ On causal mechanisms of economic influence, see: Drezner 1999/2000; Mastanduno 1992, 2003; Abdelal and Kirshner 1999/2000; and Kahler and Kastner 2006.

${ }^{38}$ Hufbauer et al 1985; Baldwin, 1999/2000; Pape 1997.

${ }^{39}$ Drezner 2003; Baldwin 1985.
} 
be hard to know in practice whether a particular country is pursuing negative economic statecraft: as Drezner writes, economic coercion is often hidden. ${ }^{40}$ Threats might be implicit, or they might be communicated in private. The problem of implicit economic coercion may be especially significant in the case of China, since Beijing has tended to take a principled stand against economic sanctions, especially those undertaken unilaterally, without United Nations' authorization. ${ }^{41}$ For instance, China reportedly shut off an oil pipeline to North Korea for several days in 2003 to pressure North Korea to enter talks with the USA. But Beijing merely cited technical problems for the cut off, denying implicitly it was economic statecraft. ${ }^{42}$ More recently, a range of Australian products (including coal, wine and lobsters) have faced difficulties entering China as tensions between Canberra and Beijing increased. Although widely seen as retaliation for recent Australian policies that have challenged PRC interests, Chinese officials have not explicitly linked these restrictions to Australian behavior, referring instead to vague factors such as "environmental protection standards."

These challenges notwithstanding, a growing number of recent studies have examined Chinese uses of coercive economic statecraft. Many of these studies have examined well-publicized cases, such as PRC sanctions directed at Taiwanese businesses that supported the Chen Shui-bian government in the early $2000 \mathrm{~s}^{44}$; PRC sanctions directed at Norway after Liu Xiaobo was awarded the Nobel Peace Prize ${ }^{45}$; and sanctions directed at South Korea during the dispute with China over THAAD deployment. ${ }^{46}$ Some of these studies have adopted a comparative approach, with the goal of generalizing about China's uses of economic sanctions. A series of studies by Reilly, for example, finds that PRC economic coercion has sometimes been successful (such as punishing the UK over Dalai Lama visits) but often fails (such as pressure on the EU to recognize China as a market economy). ${ }^{47}$

\section{Inducements}

Intentional efforts to generate economic influence can also occur through "positive" economic statecraft, where a state purposely increases economic interaction with a target state to influence the target's behavior. Positive economic statecraft can take a form that directly parallels coercive statecraft: rather than imposing economic sanctions to punish undesirable behavior, a state can promise or deliver inducements to reward desirable behavior. ${ }^{48}$ This can occur vis-à-vis a foreign government (e.g., China offers increased aid to countries that switch diplomatic recognition from Taiwan to the PRC), or vis-à-vis individuals, where officials or other politically influential actors are offered bribes to advocate for favorable policies.

\footnotetext{
40 Drezner 2003.

${ }^{41}$ Reilly 2021.

42 The Guardian, 31 March 2003: https://www.theguardian.com/world/2003/apr/01/northkorea.china.

${ }^{43}$ New York Times, 26 December 2020: https://www.nytimes.com/2020/12/26/business/coal-ships-chinaaustralia.html.

${ }^{44}$ See: Tanner 2007; Norris 2016; Kastner 2009.

${ }^{45}$ Reilly 2021; and Zhang 2019.

46 Zhang 2019.

${ }^{47}$ Reilly 2012, 2013, 2017, 2021. Comparative perspectives include Zhang 2019; and Harrell et al 2018. Fuchs and Klann (2013) argue that China punishes countries economically for hosting the Dalai Lama.

${ }^{48}$ E.g.: Drezner 1999/2000; Kahler and Kastner 2006; Baldwin 1985.
} 
The challenges of studying positive economic statecraft are in some ways even more daunting than those for negative economic statecraft. The same problems that make study of the latter difficult-implicit threats, threats communicated in private, difficulties assessing "success"-exist in spades with the former. Efforts that involve an explicit quid-pro-quo often skirt legal boundaries (e.g., bribery) and hence are likely to remain quiet or implicit. As Mastanduno notes, positive economic statecraft is tricky to study systematically because of challenges assessing whether a particular economic "carrot" is motivated by a desire for influence, or simply by a desire for economic profit. In other words, problems assessing "intent" discussed in the previous section are especially salient when examining positive economic statecraft. ${ }^{49}$

Furthermore, it is worth emphasizing that the distinction between Chinese uses of positive versus negative economic statecraft can at times be murky, as an economic incentive today can become a source of coercive leverage tomorrow. During the $\mathrm{Ma}$ Ying-jeou administration, for instance, the PRC relaxed restrictions on travel to Taiwan in order to woo Taiwan via economic incentives. But since the election of Tsai Ing-wen as Taiwan's president in 2016, Beijing has at times placed restrictions on tourism to Taiwan as part of a broader effort to pressure the Tsai government on sovereigntyrelated issues. 50

Despite these difficulties, a number of scholars have explored China's use of economic inducements to influence political outcomes. ${ }^{51}$ Some of the most sophisticated work has focused on Taiwan, where the PRC has long explicitly pursued a policy of advancing reunification via positive economic statecraft. For instance, a growing body of literature has debated the effectiveness of China's efforts to influence Taiwanese elections via the strategic purchase of agricultural products. ${ }^{52}$ Other studies have examined Chinese positive economic statecraft in cases such as Sri Lanka, Europe, and North Korea. ${ }^{53}$ And some studies have shown evidence that some economic ties with China-particularly foreign aid-might themselves be a reward for pursuing foreign policies that align with PRC preferences. ${ }^{54}$

In sum, a growing number of studies have examined China's uses of both negative and positive economic statecraft. However, the field's understanding of China's behavior in this regard is still quite limited. We are not aware of any studies that test, systematically, the efficacy of China's use of economic sanctions; indeed, we are unaware of a comprehensive effort even to catalogue China's uses of either negative or positive economic statecraft. More work is clearly needed to have a better sense of: (a) how often China seeks to use its economic ties as a tool of influence via positive or negative economic statecraft; (b) the conditions under which it is most likely to do so; and (c) the degree to which these efforts tend to be successful, and whether any such patterns emerge.

\footnotetext{
${ }^{49}$ Mastanduno 2003.

${ }^{50}$ On the tourism case, see for instance Harrell et al 2018. On PRC use of tourism in economic statecraft more broadly, see Lim et al. 2020.

${ }^{51}$ Reilly 2017, 2021; Norris 2016; Wong 2018.

${ }^{52}$ Keng et al 2017; Wei 2013; Wong and Wu 2016.

${ }^{53}$ Reilly 2017; DeVotta 2016; Reilly 2016; Lim and Mukherjee 2019; and Wong 2018.

${ }^{54}$ Dreher et al 2018.
} 


\section{Creating Vested Interests}

Economic ties with China can also lead to what Kirshner has called a "Hirschmanesque" logic, where economic ties create powerful new interest groups within other countries. ${ }^{55}$ It stands to reason that as a country becomes more economically dependent on China, a growing coalition of economic interests in that country-businesses that export to or invest in China, or that rely on Chinese products, investment, or aid-will strongly prefer stable and peaceful relations with China ${ }^{56}$ For example, violent anti-Japan protests erupted in China in 2005 after the Japanese government approved a textbook that downplayed Japanese atrocities during World War II. ${ }^{57}$ Japanese economic actors with a stake in China, in turn, had good reason to press Tokyo to avoid policies and actions that could trigger these sorts of protests. ${ }^{58}$ More recently, when Chinese trade negotiators sought to move forward a deal to end the Sino-US trade war, they met with top representatives of Wall Street firms-including the CEO of BlackRock, the world's largest asset manager-to ask their support for the deal in return for opening financial markets. As a result, Wall Street firms were beneficiaries of the trade deal signed in early $2020 .^{59}$

Studies that explore "Hirschmanesque" effects involving China do not reach uniform conclusions, however. An interesting microcosm is studies of whether the large Taiwan business community in China-the "Taishang"- has become a "conduit of influence" for Beijing. ${ }^{60}$ Although PRC officials have long subscribed to a belief that economic integration will generate Taiwanese vested interests in a stable cross-Strait political relationship, many studies suggest that the degree to which the Taishang represent a coherent "China lobby" in Taiwan should not be exaggerated. Most importantly, while some wealthy tycoons with Mainland investments have been outspoken in Taiwan politics, most Taishang tend to adopt a low profile on political matters, hoping to avoid being targeted in China or cast as villains in Taiwan. ${ }^{61}$ Taishang as a group are also not highly organized in Taiwan politics. ${ }^{62}$ Moreover, a number of studies suggest that Taiwanese living in China tend to retain a separate Taiwanese identity, ${ }^{63}$ making even less clear the extent to which Taishang represent a "pro-China" constituency. ${ }^{64}$

\footnotetext{
${ }^{55}$ Kirshner 2008; Abdelal and Kirshner 1999/2000, referring to Hirschman 1945. See also Flores-Macias and Kreps 2013; and Kastner 2016.

${ }^{56}$ On the pacifist orientation of internationalist groups, see Solingen 1998.

${ }^{57}$ Weiss 2014.

${ }^{58}$ For a recent study of Japanese business lobbying on China-related policy during the Koizumi administration, see Fu 2020, who finds that Japan's major business associations engaged in only limited efforts to dissuade visits to the Yasukuni Shrine.

${ }^{59}$ The Wall Street Journal, 2 December 2020. https://www.wsj.com/articles/china-has-one-powerful-friendleft-in-the-u-s-wall-street-11606924454. U.S. business interests played an even stronger role in China's 2001 WTO accession process. Pearson 2001.

${ }^{60}$ Tanner (2007) uses this term.

${ }^{61}$ Schubert et al 2016.

${ }^{62}$ See: Schubert et al 2016; Schubert 2013; Keng and Schubert 2010. Taishang do, however, seek close relationships with individual politicians in Taiwan; see Schubert et al. 2016: 35.

${ }^{63}$ Schubert et al. 2016: 32-34; Rigger 2011 ch. 6.

${ }^{64}$ On limitations of the Taishang as a coherent voting bloc in Taiwan, see Schubert 2013: 58-60.
} 


\section{Economic Ties can Transform Public and Elite Opinion about China}

Economic ties with the PRC also can influence broader public and elite views of China, even for those without a direct stake in those ties. Such an effect could arise through two broad processes. First, economic ties could alter public perceptions of China through the logic of soft power. Joseph Nye describes soft power as "getting others to want what you want," producing "outcomes through persuasion and attraction rather than coercion or payment." ${ }^{, 65}$ This type of attraction might occur, for instance, as a consequence of PRC investments in public goods abroad (such as critically needed infrastructure) which might in turn lead to a more benign view of Chinese intentions, among both a country's broader public and its leaders. PRC exports of personal protective equipment during the coronavirus pandemic, and its efforts to lead in vaccine distribution in developing countries, could have similar effects. And the sheer scale of China's global economic footprint is likely to affect views of China's importance as a global power. As a case in point, Pew recently found that a plurality of respondents in $32 \%$ of the 38 countries it surveyed believed that China is already the world's leading economic power. ${ }^{66}$ As Lim and Mukherjee put it, this perception of China's success could lead a target country to find China's "model of economic and political development attractive and worth emulating." ${ }^{.67}$ We return to this dynamic of host state reactions below.

Second, China might be portrayed differently in a particular domestic discourse as a result of increased dependence on Chinese capital or access to the Chinese market. Such effects could arise via investments in media outlets: Chinese companies - or, alternatively, local businesses with a large stake in China - might invest in local media within a particular country, leading to more favorable coverage of China (and censoring of stories critical of China). ${ }^{68}$ Public views of China, in turn, could become more favorable. ${ }^{69}$ Media effects could occur even more directly as Chinese media companies come to have a greater global presence. PRC media have a large presence in Africa, for example, and some research suggest that this presence has resulted in more favorable views toward China among citizens in several African countries. ${ }^{70}$ Finally, economic ties can affect China-related discourse in other countries through self-censorship that arises as a consequence of exposure to the Chinese economy. In recent years, for instance, Hollywood has gone to greater lengths to portray China in a favorable light so as to make it more likely a particular movie will be approved for release in China and also to reduce the danger of being blacklisted in the future. ${ }^{71}$ In a separate case, recent reports have suggested that China threatened to limit market access to certain companies that were deemed insufficiently deferential to China's "one China principle" with regard to Taiwan. The companies, including major US airlines, complied with PRC

\footnotetext{
${ }^{65}$ Nye 1990; Nye 2012. On a socialization process that affects elite (not mass) attitudes, see Ikenberry and Kupchan 1990.

${ }^{66}$ Pew Research Center 2017.

${ }^{67}$ Lim and Mukherjee 2019: 74.

${ }^{68}$ See Cole 2018.

${ }^{69}$ Some studies point to this type of effect in Taiwan, where businesses with China interests have invested in local media. See: Cole 2017; Schubert 2013: 62-63; and Financial Times, July 16, 2019: https://www.ft.com/ content/036b609a-a768-11e9-984c-fac8325aaa04.

${ }^{70}$ Bailiard 2016.

${ }^{71}$ On this dynamic, see Kokas 2017.
} 
demands; here, threats of sanctions were deployed against individual companies to achieve a goal of reducing Taiwan's visibility in the international arena. ${ }^{72}$ More broadly, through explicit or implicit threats to market access, individuals (e.g., pop performers $^{73}$ ) and firms may be incentivized to portray China in a favorable light and hence influence public opinion, and to avoid focus on issues, such as human rights, that might damage views of the PRC.

\section{Structural Power}

Finally, China's growing global economic links can, over time, give rise to structural power. Consider the role of the dollar in the contemporary international economy. Its centrality as the primary global reserve currency, and as the primary currency for international settlements, means that decisions made in Washington have enormous ripple effects across the globe. If and when the renminbi becomes a more formidable global reserve currency, as Beijing intends, it is conceivable that China's decisionmaking power over currency will influence the range of options open to other countries as they manage their economies. ${ }^{74}$ Similarly, the USA and Europe have had tremendous capacity to set standards in a range of domains, such as aviation, as a consequence of their market power. China also may be able to convert its firms' market power as sources of broader political influence. As Chinese companies such as Huawei potentially come to dominate certain sectors such as $5 \mathrm{G}$ communications, then China increasingly will be in a similar position where its market power means that key economic decisions increasingly are made, and standards increasingly set, in Beijing rather than Washington. This dynamic exists over and above the recent debate in the USA and elsewhere over the national security threat potentially posed by Huawei's dominance of $5 \mathrm{G}$ around the world. ${ }^{75} \mathrm{We}$ return below to the question of links between market power of firms and state influence, particularly whether Chinese firms should routinely be thought of as agents of the Chinese state.

\section{Intervening Variables}

The degree to which economic influence arises in any given case may be conditional on other variables. Authors working within the general sanctions literature have identified a range of factors that condition the effectiveness of coercive economic statecraft. ${ }^{76}$ Building on some of these insights, an increasing number of studies that examine China's economic statecraft posit that Beijing's ability to exercise economic statecraft is conditional on other variables. For instance, Norris highlights the importance of state

\footnotetext{
${ }_{72}$ Note that threats were vague in this case (we discuss the implicit nature of some Chinese economic coercion below). New York Times, 25 July 2018: https://www.nytimes.com/2018/07/25/business/taiwan-americanairlines-china.html

${ }^{73}$ China has been known to politicize market access (such as visas to perform in China) for pop music artists from Korea or Taiwan. On the Korea case, see Zhang 2019.

${ }^{74}$ Liao and McDowell (2015) find a relationship between increased usage of the renminbi and related forms of economic agreements with other countries.

${ }^{75}$ On security implications of Huawei's dominance see, e.g., New York Times 18 July 2019: https://www. nytimes.com/2019/07/18/technology/huawei-ban-vietnam.html

${ }^{76}$ On factors conditioning the efficacy of economic sanctions, see, e.g.: Blanchard and Ripsman 1999/2000; Brooks 2002; Drezner 2009.
} 
capacity to control the behavior of the firms that actually undertake interstate commerce in any given case, ${ }^{77}$ while Wong focuses on conditions set by institutions of target countries, and particularly their level of civil society participation and accountability. ${ }^{78}$

\section{Future Directions in the Study of Mechanisms}

Future studies into Chinese economic influence should, at a minimum, be cognizant that influence can arise through multiple causal processes. In turn, unless a study employs a research design that specifically tests causal processes, researchers should be cautious in attributing observed influence outcomes to a particular mechanism. More broadly, we believe that the field would benefit from more comparative studies of Chinese economic influence that address a range of big questions about the causal processes underpinning influence that remain underexplored, including: When is China most likely to use economic statecraft to try to shape policy decisions in other countries? What factors determine the type of statecraft Beijing is likely to choose? What determines whether such efforts are successful? To what degree are observed cases of apparent influence a consequence of intentional economic statecraft, or unintentional processes that arise naturally as countries become more dependent on China economically?

\section{Are Chinese Firms Agents of the State?}

Theories of economic statecraft make clear that, in the modern world, firms are crucial agents of a sending state's intentional influence strategies. ${ }^{79}$ Many if not most policy discussions of China's economic statecraft appear to take for granted alignment of goals between the central party-state and, especially, state-owned firms. And, indeed, we do know that PRC firms have sometimes been used as state agents. A high-profile example is stateowned ZTE's 2016 legal troubles in the USA. The company admitted in court documents that it followed the directives of PRC diplomats to sell technology to North Korea and Iran in contravention of international sanctions. But while an agency relationship is at times evident, scholars of China have long recognized that Beijing frequently has trouble controlling economic actors, including SOEs and policy banks (most notably the China Development Bank). ${ }^{80}$ Domestically, for example, despite attempting many dirigiste levers of control, Beijing has been unable to halt the decade-long credit and real estate bubbles. Beijing faces similar challenges as Chinese entities invest or lend overseas. The government sometimes has reined in firms that have invested or lent too aggressively abroad, as illustrated by the 2018 nationalization of Anbang Insurance Group, and the drop in foreign aid lending by China's policy banks starting around $2017 .^{81}$ The high stakes for understanding how and

\footnotetext{
${ }^{77}$ Norris 2016.

${ }^{78}$ Wong 2018.

${ }^{79}$ Baldwin 1985: 36.

${ }^{80}$ Norris (2016), for example, analyzes the agency relationship between the Chinese state and the Chinese development bank.

${ }^{81}$ Along with Anbang Insurance, private conglomerates HNA Group and Dalian Wanda were punished in early 2018 for aggressive overseas activities. Financial Times, 23 February, 2018 at https://www.ft.com/ content/8ed61466-186e-11e8-9376-4a6390addb44. On the drop in lending, see Financial Times 7 December 2020 at https://www.ft.com/content/1cb3e33b-e2c2-4743-ae41-d3fffffa4259..
} 
when Beijing exercises control over firms is exemplified in the 2019 US government banning of business between telecommunications giant Huawei and US firms and their customers/clients. We are not in a position to judge whether the US government is correct in its claim that Huawei (a privately registered firm) could be used by Beijing to gain national security advantages over the USA. But if the US ban is based on incorrect assumptions about the agency relationship, it will prove costly to businesses and consumers involved on all sides. In other words, the stakes are far from trivial. ${ }^{82}$

Several recent studies have theorized usefully about this issue. Norris analyzes statebusiness agency relationships in the context of economic statecraft and highlights potential mechanisms by which this agency relationship may operate. ${ }^{83}$ Similarly, Rithmire theorizes that agency relationships are affected by the position of various types of capital vis a vis the government. ${ }^{84}$ At the same time, a handful of early empirical studies have come to contradictory findings concerning state-business agency relationships. Most studies assume that the agency relationship will be stronger for SOEs than private enterprises. Some empirical support for such assumptions is found when comparing state and non-state trading firms in India and China. ${ }^{85}$ In contrast, a survey of Chinese SOEs and private firms finds ownership makes little difference in firms' perceptions and enthusiasm about BRI. ${ }^{86}$ Still another study of Chinese investment in Africa concludes that "just like other actors," Chinese SOEs' investments are profit-driven. $^{87}$

Given inconclusiveness of early empirical studies, it is prudent to avoid ex ante assumptions of an airtight agency relationship, especially as Chinese firms become more globalized. We distinguish three overlapping issues related to the question of state-firm agency, all of which call for further research: identifying the levers of state control over firms of various types; understanding when the state's strategic goals may be consistent with firms' commercial goals, though not necessarily identical; and detecting sources of possible de-alignment of state and firm goals.

To contextualize this discussion, it is useful to have a sense of how the relationship between firms and the state has evolved over the post-Mao period. As China's enterprise reforms picked up momentum in the 1990s, a comprehensive 1995 reform direction known informally as "grasp the big and release the small" (zhuada fangxiao) encompassed two broad trends. A cascading privatization of many "released" small and medium companies (mostly consumer service and manufacturing firms owned by local governments) legitimated the private sector, although property protections and financing were limited. "Grasping the big" meant carving out from various government ministries enormous "corporate" business groups (qiye jituan). ${ }^{88}$ These tended to be

\footnotetext{
$\overline{82}$ It will cost an estimated US\$800 million to US\$1 billion to replace Huawei and ZTE equipment in the Rural U.S. Reuters 24 September 2019, online at https:/www.reuters.com/article/us-usa-huawei-congress/u-slawmakers-propose-1-billion-fund-to-replace-huawei-equipment-idUSKBN1W931C. The example of US reactions to Japan's economic powerhouses - keiretsu - is instructive, as assumptions about their enduring power were based on questionable assumptions (Lin and Milhaupt 2013).

${ }^{83}$ Norris 2016. See also Zhang and Zhu 2018.

${ }^{84}$ Rithmire 2019.

${ }^{85}$ Davis et al (2019) find agency behavior can vary among SOEs, e.g., import-based SOEs are more likely to demonstrate agency behavior than export-oriented SOEs.

${ }^{86} \mathrm{Li}$ and Zeng 2019. See also Amighini et al 2013; and Cuervo-Cazurra et al 2014.

${ }^{87}$ Chen et al. 2018.

${ }^{88}$ On SOE reforms, see: Kroeber 2016; Lin and Milhaupt 2013.
} 
commanding heights firms in strategic industries, and often were promoted as internationally competitive "national champions." 89 These industry groups are massive, tangled, and non-transparent agglomerations. The study of agency is complicated greatly by the fact that many different sectors of Chinese firms operate overseas. ${ }^{90}$

\section{Levers of State Control Over Firms}

Several levers of Chinese state control over firms are well-known. Laws, enforceable regulations, and myriad state documents give "guidance" to firms, though often these are ambiguous and non-specific. Some of the clearest potential levers are recently enacted national security laws requiring a firm, if asked by the Chinese government, to provide information or support in the name of national security. The 2017 National Intelligence Law, for example, states.

An organization or citizen shall support, assist in and cooperate in national intelligence work in accordance with the law and keep confidential the national intelligence work that it or he knows (Article 7). ${ }^{91}$

Such language suggests that the Chinese government seeks to compel firms to serve as its agents, even if many specifics about how these laws may be enforced remain unclear. ${ }^{92}$

In addition to legal statements, Beijing has established other institutional controls over state-owned enterprises. Most obvious is the creation in 2003 of the State-Owned Assets Supervision and Administration Commission (SASAC) to oversee many of the large industry groups and formally hold them accountable for financial targets. ${ }^{93}$ The CCP maintains its own tools, most notably the power to appoint top management to SASAC-owned firms. In addition, Xi Jinping has activated a direct, though poorly understood, lever: party cells are required to exist in SOEs, with the goal of monitoring and providing guidance for following party goals. ${ }^{94}$

Despite the formal existence of these tools, they often have proven inadequate. One challenge is that firms often have multiple principals. In addition to party and SASAC (for high-profile SOEs) ties, Chinese companies located at the central level often maintain ties to their former ministerial parents, as well as to a range of other interested bureaucracies. Given that many SOE firms operating abroad are part of behemoth holding companies with great geographic and operational spread, they may be able to obscure their activities and escape control. ${ }^{95}$ Similar agency problems stemming from

\footnotetext{
${ }^{89}$ These commanding heights sectors include, e.g.: financial services, resource, telecommunications, electric power distribution, aviation, and infrastructure engineering and construction. Pearson 2015.

${ }_{90}$ Rithmire 2019.

${ }^{91}$ National Intelligence Law 2018.

92 The question of the compulsion power of Chinese laws came to prominence with the detention in Canada of a Huawei executive, at the request of the US. For this case, Chinese lawyers produced opinions that such compulsions do not exist. See Financial Times March 4, 2019 at https://www.ft.com/content/282f8ca0-3be611 e9-b72b-2c7f526ca5d0.

93 Lin and Milhaupt 2013.

94 On the CCP's appointment of top management through its Organization Department, see: Leutert 2018. Another lever of control is through party disciplinary channels, aimed at corporate corruption.

95 Lin and Milhaupt 2013: 726, 734. On multiple principals in China's "fragmented authoritarianism," see Lieberthal and Lampton 1992, and in China's overseas activities Shi 2015.
} 
central-local relations arise when SOEs are "locally owned." Local governments often demonstrate a commitment to growth of local state-owned firms, at the expense of central goals. Since, by one Chinese government estimate, $80 \%$ of the flow of state capital involved in BRI investments are from "local" companies, the issue takes on particular salience. ${ }^{96}$

Complicating the situation, state policy sets potentially contradictory goals for SOEs. For example, even the most strategic firms are mandated to be commercially successful and internationally competitive, with SASAC acting as monitor of business performance. ${ }^{97}$ Performance-based management systems that emphasize economic outcomes are used to judge all SOE managers. Indeed, documents routinely stress that the interest of "the state" is for these firms to be profitable. ${ }^{98} \mathrm{We}$ can easily imagine that these commercial goals may contradict more strategic goals.

It also is important to consider ways in which the state controls private firms, a significant segment of Chinese overseas investment. ${ }^{99} \mathrm{Xi}$ Jinping has moved to strengthen state tools to monitor private companies, notably enforcing rules to form a party cell when a private company employs three or more party members. ${ }^{100}$ Yet it is too early to know whether party cells will move beyond latent influence, except perhaps to monitor for corruption and oversee political education of party members within the firm.

For both state and private firms, once they "go out" beyond China's borders, they automatically encounter another potential check on Beijing's control: the host country. Beijing, at least rhetorically, readily cedes this challenge to its authority, often repeating the principle that its firms respect the rules of countries in which they invest. At the same time, host countries vary in their capacity to both negotiate deals with foreign investors and monitor investments. We explore this issue further below.

\section{"Same Bed, different Dreams"? Goal Alignment, Consistency, and De-alignment}

When considering agency relationships, the question of goal alignment between principals and agents is crucial. For example, do large private firms, such as Alibaba, develop digital payment systems in developing countries in order to assist the government's renminbi internationalization efforts? Or are they simply seeking increased market share abroad ${ }^{101}$ If a company's goals are consistent with the state's strategic interest, and yet distinct, the agency relationship may be less iron-clad than if the two share identical goals. Downs (2017) offers empirical evidence of this common-sense observation, arguing that national oil companies (NOCs) have taken actions that appear

\footnotetext{
${ }^{96}$ NDRC 2017: 8.

97 Economists tend to view Chinese firms' outward activities as primarily commercially motivated. See, e.g.: Kroeber 2016; Lardy 2014.

${ }^{98}$ On SOEs' focus on return on investment, see Kroeber 2016. Even state policy banks are under some pressure to engage in commercially-sound business practices.

99 According to a State Council (2016) report, in 2015 private enterprises led in foreign investment outflows and the number of mergers and acquisitions. See State Council of China 2016, "ODI Led for First Time by Private Firms" (23 September 23, 2016), at http://english.gov.cn/state_council/ministries/2016/09/23/content_ 281475449151124.htm.

${ }^{100}$ Yan and Huang 2017; Hou 2019.

${ }^{101}$ On the related issue of how close ties between data firms and the Chinese government raise suspicion overseas, see Liu (2021) in this issue.
} 
to respond to state signals, such as acquiring access to oil fields, but that these are moves the NOCs would have made anyway. More generally, if firms see economic opportunities abroad, and state policy can help, firms have reason to emphasize the ways in which they align with state goals. The many reports of firms re-labeling existing activities as "BRI initiatives" might suggest goal alignment, but may instead be commercially savvy branding exercises to signal loyalty to state goals and gain access to state funds. Alternatively, it is possible that firms go along with state initiatives only half-heartedly, especially insofar as projects involve considerable commercial risk. ${ }^{102}$ A survey by Li and Zeng (2019) finds that, to the extent firms of any type wish to participate in BRI, respondents cite opportunities for new markets and value chains, and potential for productivity gains and new technology acquisition, all of which is consistent with carrots dangled by the state. These results allow us to speculate that a significant portion of China's outward economic activity depends on firms that "go out" for their own reasons, although they may adapt to perceived Chinese state goals.

Such results further raise the intriguing question of what happens when state and firm objectives cease to align or diverge. One way to explore this question would be to examine what happens when financial and/or security risks associated with projects closely associated with Chinese foreign policy goals increase (as with the ChinaPakistan Economic Corridor). Such reasoning is suggested by the extensive literature on drivers of FDI that argues that firms prefer stability and secure property rights (especially as a credible commitment against expropriation) when investing abroad. ${ }^{103}$ At its most extreme, de-alignment can take the form of capital flight, as firms seek exit over voice or loyalty. ${ }^{104}$

Structural and economic factors may foster de-alignment from the state. Listing on foreign stock exchanges is one potential channel, putting pressure on the listed subsidiaries to follow a commercial logic. Likewise, much has been made in recent years about the rise of Chinese "venture capital" (VC). ${ }^{105}$ Many PRC-based venture capital firms invest at home but more are going overseas in the face of slowing domestic growth and domestic competition. In 2017, the amount of Chinese venture capital invested outside China doubled. ${ }^{106}$ While news reports often link this surge in VC to CCP strategic interests in, e.g., telecom and artificial intelligence, there is a lot of private money chasing deals. How readily can the Chinese state control these funds, over the long term?

Firms' dependence on global value chains in goods and services also might undermine goal alignment, as illustrated by the aforementioned case of ZTE. ZTE's sale of sanctioned technology to Iran and North Korea presumably benefited both state and commercial goals. But when the firm was caught and made subject of a major US court

\footnotetext{
102 On the hesitancy of firms to undertake risky projects, see Joy-Perez and Scissors 2018. Project risk was brought home by the terrorist attack on Chinese installations in late 2018.

103 Jensen et al 2012. Zhu and Shi (2019) demonstrate that Chinese firms prefer low-corruption environments. Paradoxically, Chen et al. (2018) argue that Chinese investment in Africa is relatively indifferent between good and poor governance environments, but tends toward investment in poor governance environments.

104 Hirschman 1970.

${ }^{105}$ More generally, "financialization" of China's economy, including SOEs, suggests pursuit of financial wealth by asset management firms may be a source of de-alignment. Wang 2015.

106 Wall Street Journal, 18 April 2018.
} 
case, ZTE agreed to submit to legal discovery of its documents, to monitoring by a Texas judge, and to punishment of top managers. Failing to comply with the first round of the case, ZTE — when courts sought a second round of punishment - submitted to further compliance measures imposed by the USA. Because ZTE's globalized business depended on access to US markets, it had no choice. ${ }^{107}$ Will other such market pressures affect de-alignment in a more general way and for other firms, even those linked to the Chinese state? An interesting area to watch in the post-Covid era will be whether China's policy banks (ExIm Bank and China Development Bank) will rankle at renegotiating debt to which they are deeply exposed, in contrast - potentially - to diplomatic goals of the government to protect China's relationships with debtor countries. ${ }^{108}$

\section{What are the "Second Order Consequences" of China's Economic Influence? Host State Reactions and Feedback Loops}

Ultimately, the political impact of China's economic rise will depend not just on China's intentions, mechanisms, and agents, but on how they are met and received outside of China. A crucial area for research therefore concerns host country agency: how do dynamics and reactions in countries exposed to China's global economic footprint shape the ways in which their governments accommodate-are influenced by - China? Such research can help identify mechanisms of the third type specified above, i.e., how economic ties shape broader public opinion in ways that either facilitate or obstruct China's influence.

Recently, a number of useful studies linking public opinion to Chinese overseas economic activities have begun to shed light on these processes, although the findings are mixed and exact mechanisms continue to need exploration. Reports that China has intended to use economic tools as strategic levers have featured negatively in political discussions among elites, and created some public backlash, in OECD countries such as New Zealand, Australia, Europe, and the USA. ${ }^{109}$ Similarly, several recent studies in political science and development economics show increases in perceptions of corruption co-located with Chinese aid and investment projects. ${ }^{110}$ Yet other studies, especially of developing countries, often show more neutral or positive views of China related to China's economic activities. ${ }^{111}$ For example, Knutsen and Kotsadam find that incumbent leaders in Africa receive no significant electoral boost from Chinese aid, but also no electoral penalty. ${ }^{112}$ Sautman and Yan find that African citizens hold quite positive views of Chinese trade activities. ${ }^{113}$ Widely varying cross-national reactions

\footnotetext{
$\overline{107}$ On ZTE's dependence on US suppliers, see Wall Street Journal 7 July 2018, https://www.wsj.com/articles/ zte-pays-1-billion-fine-after-allegedly-violating-u-s-sanctions-1528374558. The Trump administration reduced some political sanctions but the court-imposed restrictions remained. China's "Made in China 2025 " initiative and the push for "dual circulation" in the $14^{\text {th }}$ Five Year Plan (2021-2025) are efforts to counter this vulnerability.

${ }^{108}$ Chen 2020.

109 See, e.g., Brady 2015; Meunier 2014; and Setser 2008. See also fn. 1.

${ }^{110}$ Brazys and Kotsadam 2020; Isaksson and Kotsadam 2018; Knutsen et al 2017.

111 On mixed views of China in Peruvian regions with PRC investment, see Ratigan 2021. For similar results in Africa, see also Morgan 2019.

112 In contrast, an incumbent boost is associated with World Bank loans. Knutsen and Kotsadam 2020.

113 Sautman and Yan 2009.
} 
are reported in a recent study of media reports on Chinese economic activities across the globe. Drawing on a global database of media reports and measuring tone (negative-positive) across 130 countries/regions, Herrera and Xu (2019) find media opinion in Central Asia and Sub-Saharan Africa quite positive, in contrast to sentiment in North America, Latin America, and South Asia.

Future research should explore host country reactions on numerous dimensions, as well as variance, at greater length. It stands to reason, for example, that efforts by China to leverage economic relationships into political influence are less successful where there are negative popular views of China's economic presence, or where the presence of Chinese firms is linked with sectors known for corruption, compared with areas with a more positive baseline of opinion or in sectors seen as "modern," such as financial services. Wong, as noted above, finds that host domestic institutions - especially - play an important role in shaping domestic reactions and ultimately in influencing the effectiveness of China's economic statecraft. ${ }^{114}$ Perceptions of concrete political benefits can lead host country leaders to compete for Chinese-funded projects in their home districts. ${ }^{115}$ In yet another dynamic, negative host country reactions to China may be activated by political competition in the host country rather than by Chinese behavior itself. In the much-discussed case of Sri Lanka's Hambantota port, for example, the relationship of incumbent leaders to Chinese investment has become a domestic political football, leading to significant backlash but also demonstrating how the narrative of China's "influence" takes on a life of its own. ${ }^{116}$

In contrast to these examples in which Chinese intent to influence tends to be assumed, host country reactions also are created when influence may not be Beijing's intent. In other words, reactions to China may be created via unintentional structural influence, although interpreted (or framed) in affected countries as results of explicit Chinese influence attempts. For example, whereas much political discussion in the USA about China's persistent bilateral trade surplus is framed to suggest Beijing's intention to strengthen China at the expense of the USA, the sheer volume of US demand (and the displacement of US workers jobs) would likely lead to backlash against China regardless of whether deficits are related to commercial factors or to strategic intent. ${ }^{117}$ On the other hand, the World Bank's BRI Research unit argues that just by increasing connectivity, poor countries should benefit from increased growth. It is thus plausible that reactions in host countries may be positive if growth related to China increases.

Thus, the classic political economy question of "who wins and who loses" from China's economic activity, and how these perceptions are processed through domestic politics in host countries, is crucial to study. Varying reactions by elites and citizens, and changes in these perceptions over time, will help uncover key mechanisms for the effectiveness of China's expanded economic footprint.

Beijing's concerns about negative reactions to its outward economic activities also have prompted subsequent changes on its part, creating a feedback loop in China's policy process. High-profile criticism, both domestic and international, of BRI projects

\footnotetext{
114 See Wong 2018 and country studies in Goh 2016. This raises the intriguing question of whether Chinese overseas activities are themselves endogenous to expectations of backlash. See, e.g., Han et al 2018.

115 Dreher et al 2019.

${ }^{116}$ Pekkanen and Pearson 2018.

117 Autor et al 2016.
} 
and development lending spurred China to strengthen its regulatory framework to improve its international image and to mitigate risk. For example, MOFCOM sets a credit system for Chinese overseas companies that punishes those that harm China's image, such as for environmental degradation. Chinese authorities also produced rules to incentivize positive firm investment and bank lending behavior. ${ }^{118}$ Firms also have been pressured to strengthen corporate social responsibility beyond what may be required by the host country. ${ }^{119}$ Recognition of problems in China's overseas performance, and reactions to it, has been evident in the more tempered comments by Xi Jinping at major BRI-related fora, as well as in the substantial reductions in lending after 2017. ${ }^{120}$ The policy feedback and evolution of policy suggest the need to take a long-term view toward understanding the global political impact of China's global economic rise.

\section{Conclusion}

The prospects for China to leverage its economic rise into global political influence are front and center on the agenda of academic researchers and government policy-makers. Given the significance of this topic, we expect that this flood of material will not slow down any time soon. We embarked on this article with the observation that researchers and policy analysts alike would be well-served by a discussion of what current theory and early studies of China's influence can tell us, as well as discussion of the difficulties inherent in the undertaking. We argue that major work remains to be done through the whole logic chain of inquiry. In particular, we have focused on the need to address directly problematic conceptual and research design issues in the study of China's influence, most notably, difficulties identifying China's "true" versus potentially conflicting objectives, fleshing out the mechanisms for successful influence, understanding how the PRC's economic agents may and may not carry out Beijing's agenda, and understanding the reactions in host countries arising from China's expanding economic reach, as well as feedback loops that affect subsequent Chinese behavior. We have made some specific suggestions as to agenda items that will help answer these questions.

More broadly, we wish to emphasize that research design issues are not easily solved, and that given the sprawling and diverse nature of China's overseas activities, researchers are likely to uncover many diverse mechanisms related to the nature of China's goals and its ability (or lack thereof) to align its agents. The impact of China's foreign economic ties also may not be exactly what Beijing intends: while China's leaders may succeed in leveraging economic interactions to carry out influence, we

\footnotetext{
${ }^{118}$ On domestic concerns about "blind and irrational investment," see New York Times 12 March 2017, available at https://www.nytimes.com/2017/03/12/business/dealbook/china-deals-capital-controls-hollywood. $\mathrm{html}$. Some of these rules aimed to prevent the movement of funds offshore. This was the main point of a late 2017 36-point code of conduct. Forbes online (Dec. 22, 2017), available at https://www.forbes.com/sites/ sarahsu/2017/12/22/china-tightens-overseas-investment-to-reduce-risks/\#7d853295772c.

${ }^{119}$ Chinese NGO efforts to strengthen corporate social responsibility of its firms' overseas operations have been supported by UN agencies (such as UNDP) and international NGOs, such as Global Witness.

${ }^{120}$ On learning, see Hillman 2020 and, for example, Xi 2019. On reductions in overseas loans, see Financial Times 7 December 2020 at https://www.ft.com/content/1cb3e33b-e2c2-4743-ae41-d3fffffa4259.
} 
have shown why it may fail to obtain the influence it hopes for and reap either good or ill from effects that it does not (initially) intend. Finally, it is crucial for researchers to query the ways in which host countries themselves shape the impact of China's economic rise and potential influence. Each of these elements of the inquiry logic chain is likely to evolve over time, guaranteeing that this will be a subject worthy of long-term attention.

Acknowledgements The authors wish to thank the following for valuable comments on earlier drafts of this article: Rumi Aoyama, David Bachman, Isaac Kardon, Alastair Iain Johnston, Chad Rector, Jessica Chen Weiss, and participants in workshops at the 2020 Annual Meeting of APSA, Cheng-chi University, CNA, National Defense University, University of Delaware, and University of Washington.

\section{References}

Abdelal R, Kirshner J. Strategy, economic relations, and the definition of national interests. Security Stud. 1999/2000;9(1/2):119-56.

Amighini A, Rabellotti R, Sanfilippo M. Do Chinese state-owned and private enterprises differ in their internationalization strategies? China Econ Rev. 2013;27:312-25.

Autor D, Dorn D, Hanson GH. The China shock: learning from labor market adjustment to large changes in trade. Ann Rev Econ. 2016;8(1):205-40. https://doi.org/10.3386/w21906.

Bailiard CS. China in Africa: an analysis of the effect of Chinese media expansion on African public opinion. Int J Press/Polit. 2016;21(4):446-71.

Baldwin DA. Economic statecraft. Princeton: Princeton University Press; 1985.

Baldwin DA. The sanctions debate and the logic of choice. IntSecur. 1999/2000;24(3):80-107.

Blanchard JF. Probing China's $21^{\text {st }}$ century Maritime Silk Road Initiative (MSRI): an examination of MSRI narratives. Geopolitics. 2017;22(2):246-68.

Blanchard JF, Ripsman NM. Asking theright questions:when doeconomic sanctionsworkbest? SecurStud. 1999/2000;9(1/2):219-53.

Brady AM. China's foreign propaganda machine. J Democr. 2015;26(4):51-9.

Bräutigam D. A critical look at chinese 'debt-trap diplomacy': the rise of a meme. Area Dev Policy. 2020;5(1): 1-14. https://doi.org/10.1080/23792949.2019.1689828.

Bräutigam D, Tang X. Economic statecraft in China's new overseas special economic zones: soft power, business or resource security? IntAff. 2012;88(4):799-810.

Brazys S, Kotsadam A. Sunshine or curse? foreign direct investment, the OECD anti-bribery convention, and individual corruption experiences in Africa. Int Stud Q. 2020;64(4):956-96.

Brooks RA. Sanctions and regime type: what works, and when? Secur Stud. 2002;11(4):1-50.

Chen M. Beyond donation: China's policy banks and the reshaping of development finance. Stud Comp Int Dev. 2020;55:436-59. https://doi.org/10.1007/s12116-020-09310-9.

Why is China investing in Africa? evidence form the firms level. World Bank Econ Rev. 2018;32(3):610-32 (https://elibrary.worldbank.org/doi/10.1093/wber/lhw049).

Cole JM. The hard edge of sharp power: understanding China's influence operations abroad. Ottawa: Macdonald-Laurier Institute; 2018.

Cole JM. Convergence or conflict in the Taiwan strait: the illusion of peace? New York: Routledge; 2017.

Cuervo-Cazurra A, Inkpen A, Musacchio A, Ramaswamy K. Governments as owners: state-owned multinational companies. J Int Bus Stud. 2014;45(8):919-42.

Davis C, Fuchs A, Johnson K. State control and the effects of foreign relations on bilateral trade. J ConflResolut. 2019;63(2):287-316.

DeVotta N. China's influence in Sri Lanka: negotiating development, authoritarianism, and regional transformation. In: Goh E, editor. Rising China's influence in developing asia. Oxford: Oxford University Press; 2016. p. 129-52. 
Downs E. China's national oil companies return to the world stage: navigating anticorruption, low oil prices, and the belt and road initiative Asia's energy security and China's belt and road initiative. Seattle: National Bureau of Asian Research; 2017.

Dreher A, Fuchs A, Parks B, Strange AM, Tierney MJ. Apples and dragon fruits: the determinants of aid and other forms of state financing from China to Africa. Int Stud Quart. 2018;62(1):182-94.

Dreher A, Fuchs A, Hodler R, Parks BC, Raschky PA, Tierney MJ. African leaders and the geography of China's foreign assistance. J Dev Econ. 2019;140:44-71.

Drezner DW. Bad debts: assessing China's financial influence in great power politics. IntSecur. 2009;34(2):745.

Drezner DW. The hidden hand of economic coercion. Int Organ. 2003;57:643-59.

Drezner DW. The trouble with carrots: transaction costs,conflictexpectations, andeconomic inducements. Secur Stud. 1999/2000;9(1/2):188-218.

Eisenman J, Heginbotham E, editors. China steps out: Beijing's major power engagement with the developing world. New York: Routledge; 2018.

Ferchen M, Perera A. Why unsustainable Chinese infrastructure deals are a two way street. Carnegie-Tsinghua center for global policy, 22 July 2019: https://carnegietsinghua.org/2019/07/23/why-unsustainablechinese-infrastructure-deals-are-two-way-street-pub-79548.

Flores-Macias GA, Kreps SE. The foreign policy consequences of trade: China's commercial relations with Africa and Latin America, 1992-2006. J Polit. 2013;75(2):357-71.

Fravel TA, Manion M, Wang YH. A 'China in the world' paradigm for scholarship. Studies in comparative international development.

Friedberg AL. Globalisation and Chinese grand strategy. Survival. 2018;60(1):7-40.

Fu, RT. Testing one key causal mechanism of hirschmanesque effects: Koizumi's visits to Yasukuni Shrine as a negative case. Paper presented to the Hong Kong University China influence workshop, December 2020.

Fuchs A, Klann NH. Paying a visit: the Dalai Lama effect on international trade. J Int Econ. 2013;91:164-77.

Fuchs A, Rudyak M. The motives of China's foreign aid. In: Handbook of the international political economy of China. London: Edward Elgar Publishers; 2019.

Gaventa J. Power and powerlessness: quiescence and rebellion in an appalachian valley. Urbana: University of Illinois Press; 1982.

Glosny M. Chinese assessments of China's influence in developing asia. In: Goh E, editor. Rising China's influence in developing asia. Oxford: Oxford University Press; 2016. p. 24-51.

Goh E, editor. Rising China's influence in developing asia. Oxford: Oxford University Press; 2016.

Han X, Liu XH, Gao L, Ghauri P. Chinese multinational enterprises in Europe and Africa: how do they perceive political risk? ManagInt Rev. 2018;58(1):121-46.

Harrell P, Rosenberg E, Saravalle E. China's use of coercive economic measures. Washington: Center for a New American security; 2018. https://www.cnas.org/publications/reports/chinas-use-of-coerciveeconomic-measures.

Herrera AG, Xu JW. Countries' perceptions of China's belt and road initiative: a big data analysis. Bruegel working paper 1. Brussels Breugel Institute; 2019.

Hillman JE. The Emperor's new road: China and the project of the century. New Haven: Yale University Press; 2020.

Hirschman AO. Exit, voice, and loyalty: responses to decline in firms, organizations, and states. Cambridge: Harvard University Press; 1970.

Hirschman AO. National power and the structure of foreign trade. Berkeley: University of California Press, 1945 [1980].

Yue H. The private sector: challenges and opportunities during Xi's second term. China leadership monitor 2019;59.

Hufbauer GC, Schott JJ, Elliot KA. Economic sanctions reconsidered. Washington: Institute for International Economics; 1985.

Ikenberry GJ, Kupchan CA. Socialization and hegemonic power. Int Organ. 1990;44(3):283-315.

Isaksson AS, Kotsadam A. Chinese aid and local corruption. J Public Econ. 2018;159:146-59.

Jensen NM, Biglaiser G, Li Q, Malesky E, Pinto PM, Pinto SM, Staats JL. Politics and foreign direct investment. Ann Arbor: University of Michigan Press; 2012. 
Jones L, Zeng JH. Understanding China's 'belt and road initiative': beyond 'grand strategy' to a state transformation analysis. Third World Q. 2019;40(8):1415-39. https://doi.org/10.1080/01436597.2018. 1559046.

Joy-Perez C, Scissors D. The Chinese state funds belt and road but does not have trillions to spare. Washington: American Enterprise Institute 2018. http://www.aei.org/publication/the-chinese-statefunds-belt-and-road-but-does-not-have-trillions-to-spare/.

Kahler M, Kastner SL. Strategic uses of economic interdependence: engagement policies on the Korean Peninsula and across the Taiwan Strait. J Peace Res. 2006;43(5):523-41.

Kardon, I. Pier competitor: testimony on China's global ports. Naval War Coll Rev. 2021; 74 (1).

Kastner SL. Buying influence? assessing the political effects of China's international trade. J Conflict Resolut. 2016;60(6):980-1007.

Kastner SL. Political conflict and economic interdependence across the Taiwan Strait and beyond. Stanford: Stanford University Press; 2009.

Keng S, Schubert G. Agents of Taiwan-China unification? the political role of Taiwan business people in the process of cross-strait integration. Asian Surv. 2010;50(2):287-310.

Keng S, Tseng JYC, Yu Q. The strengths of China's charm offensive: change in the political landscape of a Southern Taiwan town under attack from Chinese economic power. China Q. 2017;232:956-81.

Khanna P. Washington is dismissing China's belt and road. That's a huge strategic mistake. Politico, 30 April 2019: https://www.politico.com/magazine/story/2019/04/30/washington-is-dismissing-chinas-belt-androad-thats-a-huge-strategic-mistake-226759.

Kirshner J. The consequences of China's economic rise for Sino-U.S. relations: rivalry, political conflict,and (not)war. In: Ross RS, Feng ZHU, editors, China’s ascent. Ithaca: Cornell University Press, 2008.

Knutsen CH, Kotsadam A. The political economy of aid allocation: aid and incumbency at the local level in sub Saharan Africa. World Dev. 2020;127:104729.

Knutsen CH, Kotsadam A, Olsen EV, Wig T. Mining and local corruption in Africa. Am J PolitSci. 2017;61(2):320-34.

Kokas A. Hollywood made in China. Oakland: University of California Press; 2017.

Kroeber AR. China's economy: what everyone needs to know. New York: Oxford University Press; 2016.

Lardy NM. Markets over mao: the rise of private business in China. Washington: Peterson Institute for International Economics; 2014.

Leutert W. Firm control: governing the state-owned economy under Xi Jinping. China Perspect. 2018;1(2): 27-36.

Liao S, McDowell D. Redback rising: China's bilateral swap agreements and renminbi internationalization. Int Stud Quart. 2015;59(3):401-22. https://doi.org/10.1111/isqu.12161.

Li XJ, Zeng K. To join or not to join? state ownership, commercial interests, and China's belt and road initiative. Pac Aff. 2019;92(1):5-26.

Lieberthal K, Oksenberg M. Policy making in China: leaders, structures, and processes. Princeton: Princeton University Press; 1988.

Lieberthal K, Lampton DM, editors. Bureaucracy, politics, and decision making in post-Mao China. Berkeley: University of California Press; 1992.

Lin LW, Milhaupt CJ. We are the (National) champions: understanding the mechanisms of state capitalism in China. Stanford Law Rev. 2013;65:697-759.

Lim D, Ferguson V, Bishop, R. Chinese outbound tourism as an instrument of economic statecraft. J Contemp China, published online March 26, 2020: SSRN: https://ssrn.com/abstract=3484162.

Lim D, Mukherjee R. What money can't buy: the security externalities of Chinese economic statecraft in postwar Sri Lanka. Asian Secur. 2019;15(2):73-92.

Liu LZ. The Rise of Data Politics: Digital China and the World. Studies in Comparative International Development 2021

Lukes S. Power: A Radical View. London: Macmillan Books; 1974.

Mastanduno M. Economic Containment: CoCom and the Politics of East-West Trade. Ithaca: Cornell University Press, 1992.

Mastanduno M. The Strategy of Economic Engagement: Theory and Practice. In: Mansfield ED, Pollins BM, editors. Economic Interdependence and International Conflict: New Perspectives on an Enduring Debate. Ann Arbor: University of Michigan Press; 2003. p. 175-86.

Meunier S. Divide and Conquer? China and the cacophony of foreign investment rules in the EU. J Eur Public Policy. 2014;21(7):996-1016. 
Morgan P. Can China's Economic Statecraft Win Soft Power in Africa? Unpacking Trade, Investment and Aid. J Chin PolitSci. 2019;24(3):387-409. https://doi.org/10.1007/s11366-018-09592-w.

National Development and Reform Commission (NDRC), Ministry of Foreign Affairs and Ministry of Commerce PRC, Vision and Proposed Actions Outlined on Jointly Building Silk Road Economic Belt and 21st Century Maritime Silk Road 2015: http://www.cn.undp.org/content/dam/china/docs/ Publications/UNDP-CH-GGR\%202017.pdf.

NDRC, Report on China's Outward Foreign Investment. Beijing: People’s Publishing, 2017.

National Intelligence Law of the People's Republic of China (Promulgated by Order No. 69 of the President of the PRC June 27, 2017, amended 27 April 2018. http://en.pkulaw.cn/display.aspx?cgid=313975\&lib= law.

Norris WJ. Chinese Economic Statecraft: Commercial Actors, Grand Strategy, and State Control. Ithaca: Cornell University Press; 2016.

Nye JS. Soft Power. Foreign Policy. 1990;80:153-71.

Nye JS. Why China is Weak on Soft Power. New York Times 7 January 2012: https://www.nytimes.com/2012/ 01/18/opinion/why-china-is-weak-on-soft-power.html.

Pape RA. Why Economic Sanctions Do Not Work. IntSecur. 1997;22(2):90-136.

Pearson MM. The Case of China's Accession to GATT/WTO. In: Lampton DM, editor. The Making of Chinese Foreign and Security Policy in the Era of Reform. Stanford: Stanford University Press; 2001. p. 337-70.

Pearson MM. State-Owned Business and Party-State Regulation in China's Modern Political Economy. In Naughton B and Tsai K, editors, State Capitalism, Institutional Adaptation, and the Chinese Miracle, Cambridge University Press 2015: 27-45.

Pekkanen, SM and MM Pearson, 2018, Limits to Maritime Power: The Politics of Controversy over Chinese Infrastructure Investment" 2018. https://papers.ssrn.com/sol3/papers.cfm?abstract_id=3285430

Pew Research Center. Globally More Name US Than China as World's Leading Economic Power. 13 July 2017. https:/www.pewresearch.org/global/2017/07/13/more-name-u-s-than-china-as-worldsleading-economic-power/.

$\mathrm{Pu}$ XY, Schweller R. Status Signaling, Multiple Audiences, and China’s Blue-Water Naval Ambition. In Paul TV, Larson DW and Wohlforth WW, eds., Status in World Politics. Cambridge University Press, 2014: 141-163.

Ratigan, K. Are Peruvians Enticed by the "China Model"? Chinese Investment and Public Opinion in Peru. Studies in Comparative International Development.

Reilly J. China's Economic Statecraft: Turning Wealth into Power Lowy Institute Analysis. Sydney: Lowy Institute for International Policy; 2013.

Reilly J. China's Economic Statecraft in Europe. Asia Eur J. 2017;15(2):173-85.

Reilly J. China's Unilateral Sanctions. The Washington Quarterly, Fall 2012: 121-133.

Reilly J. Chinese Sunshine: Beijing's Influence on Economic Change in North Korea. In: Goh E, editor. Rising China's Influence in Developing Asia. Oxford: Oxford University Press; 2016. p. 193-216.

Reilly J. Orchestration: China's Economic Statecraft across Europe and Asia. New York: Oxford University Press; 2021.

Rigger S. Why Taiwan Matters: Small Island, Global Powerhouse. Lanham: Rowman and Littlefield; 2011.

Rithmire M. Varieties of Outward Chinese Capital: Domestic Politics Status and Globalization of Chinese Firms. Harvard Business School Working Paper 20-009. Cambridge: Harvard Business School, 2019.

Rolland N. Beijing's Response to the Belt and Road Initiative's 'Pushback': A Story of Assessment and Adaptation. Asian Aff. 2019;50(2):216-35.

Russel DR. Berger BH. Weaponizing the Belt and Road Initiative. Asia Society Policy Institute Report September 2020. New York: Asia Society Policy Institute. https://asiasociety.org/sites/default/files/ 202009/Weaponizing\%20the\%20Belt\%20and\%20Road\%20Initiative_0.pdf

Saunders, PC. China's Global Activism: Strategy, Drivers, and Tools. Occasional Paper 2006;4. Institute for National Strategic Studies, National Defense University.

Sautman B, Yan HR. African Perspectives on China-Africa Links. China Quarterly 2009;199: 728-259. https://doi.org/10.1017/S030574100999018X

Schubert G. Assessing Political Agency across the Taiwan Strait: the Case of the Taishang. China Information. 2013;27(1):51-79.

Schubert G, Lin RH, Tseng JYC. Taishang Studies: A Rising or Declining Research Field? China Perspectives. 2016;1:29-36. 
Setser BW. Sovereign Wealth and Sovereign Power: The Strategic Consequences of American Indebtedness. New York: Council on Foreign Relations Press; 2008.

Shi, WY. The Political Economy of China's Outward Direct Investments. Ph.D. Dissertation. University of California, San Diego, 2015.

Snyder J. Myths of Empire: Domestic Politics and International Ambition. Ithaca: Cornell University Press; 1991.

Solingen E. Regional Orders at Century's Dawn: Global and Domestic Influences on Grand Strategy. Princeton: Princeton University Press; 1998.

State Council of China, Action Plan on the Belt and Road Initiative (March 30, 2015). http://english.gov.cn/ archive/publications/2015/03/30/content_281475080249035.htm.

State Council of China, ODI Led for First Time by Private Firms" (23 September 23, 2016). http://english.gov. cn/state_council/ministries/2016/09/23/content_281475449151124.htm.

State Council Information Office (SCIO) White Paper, China's Policies on Asia-Pacific Security Cooperation. January 2017 http://www.xinhuanet.com//english/china/2017-01/11/c_135973695.htm.

State Oceanic Administration. 2016 Ocean Development Report. Beijing: Haiyang Press; 2016.

Tanner MS. Chinese Economic Coercion against Taiwan: A Tricky Weapon to Use. Santa Monica: RAND Corporation; 2007.

U.S. - China Economic and Security Review Commission Annual Report to Congress, 2018: https://www. uscc.gov/Annual_Reports/2018-annual-report.

U.S. Department of Defense, Assessment of U.S. Defense Implications of China's Expanding Global Access. December 2018: https://media.defense.gov/2019/Jan/14/2002079292/-1/-1/1/EXPANDING-GLOBALACCESS-REPORT-FINAL.PDF,

Wang YY. 'The Rise of the 'Shareholding State': Financialization of Economic Management in China. Soc Econ Rev. 2015;13(3):603-25.

Wei CH. China's Economic Offensive and Taiwan's Defensive Measures: Cross-Strait Fruit Trade, 20052008. China Q. 2013;215:641-62.

Weiss JC. Powerful Patriots: Nationalist Protest in China's Foreign Relations. New York: Oxford University Press; 2014.

Wong A. Crafting Payoffs: Strategies and Effectiveness of China's Economic Statecraft. Boston: Annual meeting of the American Political Science Association; 2018.

Wong SHW, Wu N. Can China Buy Taiwan? An Empirical Assessment of Beijing's Agricultural Trade Concessions to Taiwan. J Contemp China. 2016;25 (99): 353-71.

Wuthnow J. Chinese Perspectives on the Belt Road Initiative. China Strategic Perspectives No. 12. Washington, DC: National Defense University Press, 2017. https://inss.ndu.edu/Portals/68/Documents/ stratperspective/china/ChinaPerspectives-12.pdf.

Wuthnow J. Deciphering China's Intentions: What Can Open Sources Tell Us? Asan Forum 2019;29.

Xi J. "Secure a Decisive Victory in Building a Moderately Prosperous Society in All Respects and Strive for the Great Success of Socialism with Chinese Characteristics for a New Era." Speech delivered at the 19th National Congress of the Communist Party of China October 18, 2017. English translation at: http://www. xinhuanet.com/english/download/Xi_Jinping's_report_at_19th_CPC_National_Congress.pdf.

Xi J. 2019. "Working Together to Deliver a Brighter Future For Belt and Road Cooperation.” Keynote Speech at the Opening Ceremony of the Second Belt and Road Forum for International Cooperation, April 26, 2019. English translation at Working Together to Deliver a Brighter Future For Belt and Road Cooperation (fmprc.gov.cn).

Yan XJ, Huang J. Navigating Unknown Waters: The Chinese Communist Party's New Presence in the Private Sector. China Rev. 2017;17(2):37-63.

Yarhi-Milo K. Knowing the Adversary: Leaders, Intelligence, and Assessment of Intentions in International Relations. Princeton University Press, 2014.

Ye M. The Belt Road and Beyond: State-Mobilized Globalization in China: 1998-2018. Cambridge University Press 2020.

Zhang KTV. Chinese Non-Military Coercion: Tactics and Rationale. Washington, DC: Brookings Institution, 2019. https://www.brookings.edu/articles/chinese-non-military-coercion-tactics-and-rationale/.

Zhang XK, Zhu TB, eds. Business, Government and Economic Institutions in China. London: Palgrave Macmillan, 2018. 
Zhao S. Economic Interdependence and Political Divergence: A Background Analysis of the Taiwan Strait Crisis. In: Zhao S, editor. Across the Taiwan Strait: Mainland China, Taiwan, and the 1995-1996 Crisis. New York: Routledge; 1999. p. 21-40.

Zhi Q, Pearson MM. China's Hybrid Adaptive Bureaucracy: The Case of the 863 Program for Science and Technology. Governance. 2017;30(3):407-42.

Zhu BL, Shi WY. Greasing the Wheels of Commerce? Corruption and Foreign Investment. J Polit. 2019;81(4):1311-27.

Publisher's Note Springer Nature remains neutral with regard to jurisdictional claims in published maps and institutional affiliations.

Scott L. Kastner is a Professor in the Department of Government and Politics at the University of Maryland, College Park. He is author of China's Strategic Multilateralism: Investing in Global Governance (Cambridge University Press, 2019; with Margaret Pearson and Chad Rector) and Political Conflict and Economic Interdependence across the Taiwan Strait and Beyond (Stanford University Press, 2009). His research has also appeared in journals such as International Security, International Studies Quarterly, Journal of Conflict Resolution, Comparative Political Studies, and Security Studies.

Margaret M. Pearson is Dr. Horace E. and Wilma V. Harrison Distinguished Professor in the Department of Government and Politics, University of Maryland, College Park. She is author of China's Strategic Multilateralism: Investing in Global Governance (with Scott L. Kastner and Chad Rector, Cambridge University Press, 2019), China's New Business Elite: The Political Results of Economic Reform (University of California Press, 1997), and Joint Ventures in the People's Republic of China (Princeton University Press, 1991). Her research also has appeared in World Politics, Security Studies, The China Journal, Public Administration Review, Governance, and Review of International Political Economy. 